\title{
Urokinase type plasminogen activator receptor expression in colorectal neoplasms
}

S Suzuki, Y Hayashi, Y Wang, T Nakamura, Y Morita, K Kawasaki, K Ohta, N Aoyama, S R Kim, H Itoh, Y Kuroda, W F Doe number of different molecules including proteolytic enzymes, adhesion molecules, and growth factors. ${ }^{3-5}$

Urokinase type plasminogen activator (uPA) is an extracellular serine protease that mediates focal proteolysis and cotributes to cancer invasion and metastasis by catalysing conversion of plasminogen into plasmin, which degrades extracellular matrix (ECM) and activates latent proteases..$^{6-9}$ uPA activation occurs on the cell surface after binding to its specific receptor (UPAR) and is regulated by the number of UPAR and the concentration of its specific inhibitors (PAIs), which include plasminogen activator inhibitor type 1 (PAI-1), type 2 (PAI2 ), and proteinase nexin-1. ${ }^{10-16}$ Previous studies have implicated uPA activated cell surface activity in clinical behaviour of tumours as well as in tumour invasion and metastasis, ${ }^{17-29}$ especially in colorectal cancer. uPA content is significantly higher in adenomatous polyps and carcinomas than in normal mucosa, ${ }^{30-37}$ and uPA mRNA has been localised in stromal cells. $^{38}{ }^{39}$ PAI-1 mRNA is located in endothelial cells in the tumour stroma, ${ }^{40}$ and the activity and antigen levels of both PAI-1 and PAI-2 also increase in adenomatous polyps and carcinomas. $^{30} 314142$

Among the molecular components of the uPA system, uPAR expression on the surface of tumour cells seems to be central to the invasion process. The expression of UPAR has been reported in colon cancer ${ }^{38}{ }^{43}$ and other types of malignancies, ${ }^{12} 1418-2344$ and has been shown to facilitate extracellular matrix invasion by colon cancer. ${ }^{13}{ }^{45-47}$ Experimental evidence from in vitro and in vivo models also suggests a correlation between UPAR expression and cancer aggressiveness involving tumour growth, invasiveness, and metastasis. ${ }^{48-50}$ Furthermore, the functions of UPAR have recently been investigated with regard to cell attachment and migration during the overall process of invasion and metastasis. ${ }^{51-56}$

It is widely accepted that the majority of colorectal carcinomas arise from adenomatous polyps of malignant potential. ${ }^{57}$ Various genetic changes with epithelial dysplasia have been shown in adenomas. Regarding the uPA system, several studies have reported that uPA expression and proteolytic activity increased in parallel with the sequence of normal mucosaadenoma-carcinoma in colon. ${ }^{33-37415859}$ The relation between UPAR expression and carcinogenesis, however, remains to be shown.

In this study, we have analysed colorectal neoplasms representing the progression of the adenoma-carcinoma sequence from mild dys-
Accepted for publication 4 June 1998
First Divisio
Pathology
S Suzuki
Y Hayashi
Y Morita
H Itoh
First Division
Surgery
T Nakamura
K Kawasaki
K Ohta
Y Kuroda
Second Divis
Internal Med
Kobe Unive
School of M
Kobe, Japan
N Aoyama
Division of
Gastroenter

Division of Molecular Research, Australian National University, Correspondence to: of Pathology, Kobe Medicine, 7-5-1 Kusunoki-cho, Chuo-ku, Kobe 650, Japan. \begin{abstract}
esis, adhesion, proteolysis, migration, and proliferation. ${ }^{12}$ These complex processes involve many interactions between cancer cells, components of the extracellular matrix, and a

Recent studies suggest that cancer invasion and metastasis arise through a sequence, or an receptor; colorectal adenoma; colorectal cancer; adenoma-carcinoma sequence
\end{abstract}


plasia through to carcinoma in situ. We have studied invasive cancer and metastasis by qualitative and quantitative techniques for UPAR gene transcript and protein, and report the significance of UPAR expression during the development of colorectal cancer.

\section{Materials and methods}

MATERIALS

Tissue samples were collected after surgical or endoscopic resection. Tumour and normal tissues were divided in two: one part was frozen in liquid nitrogen and stored at $-80^{\circ} \mathrm{C}$ for RNA and protein extraction; the other was fixed with $4 \%$ paraformaldehyde in $0.1 \mathrm{M}$ phosphate buffer, $\mathrm{pH} 7.0$, at $4^{\circ} \mathrm{C}$ overnight. The samples were then dehydrated with a series of ethanol and defatted with chloroform and embedded in paraffin. Longitudinal sections ( $4 \mu \mathrm{m}$ thick) were cut and mounted on slides coated with 3-(triethoxysilyl)propylamine (Merck, Darmstadt, Germany) for immunohistochemical staining and in situ hybridisation. Routine staining methods using haematoxylin and eosin were carried out in adjacent sections. All specimens were classified according to standard histological criteria. ${ }^{60}$

One hundred specimens were classified as adenoma with various grades of dysplasia characterised by cells with hyperchromatic, crowded, elongated, and stratified nuclei, increasing mitotic activity, loss of nucleus polarity, decreasing mucus secretion, and changing of crypt structure. The diagnostic grade of the 100 adenomas, based on the most severely dysplastic area, was as follows: mild dysplasia (31), moderate dysplasia (33), and severe dysplasia (36) containing carcinoma in situ (20). Eighty specimens of invasive carcinoma were staged according to Dukes' classification. ${ }^{61}$ These were 29 stage A tumours limited to the bowel wall, 28 stage B tumours penetrating the muscularis propria, and 23 stage $\mathrm{C}$ tumours spreading to involve the regional lymph nodes. Three metastatic colorectal carcinomas of the liver were also studied.

PREPARATION OF RNA AND CDNA PROBES

Digoxigenin labelled single strand RNA probes were prepared with a DIG RNA Labelling Kit (Boehringer Mannheim GmbH Biochemica, Mannheim, Germany) according to the manufacturer's instructions for in situ hybridisation. For generating the human uPAR probe, the $585 \mathrm{bp} \mathrm{BamHI}$ and $268 \mathrm{bp}$ PstI fragments of the UPAR cDNA clone were subcloned into the Vector pGEM-3Z (Promega, Wisconsin, USA). These plasmids were linearised with either HindIII and transcribed with T7 RNA polymerase to generate an antisense (cRNA) probe, or with EcoRI (for the $585 \mathrm{bp} \mathrm{BamHI}$ fragment) or AccI (for the $268 \mathrm{bp}$ PstI fragment) and transcribed with SP6 RNA polymerase to generate a sense probe. To acquire DIG labelled cDNA fragments as probes for northern blot analysis, the Vector pGEM-3Z subcloned by the 585 bp BamH1 fragment was amplified by polymerase chain reaction (PCR) with PCR DIG Probe Synthe- sis Kit (Boehringer Mannheim), using RNA polymerase promoter sequencing primers, T7 and SP6 (Promega).

IN SITU HYBRIDISATION

The in situ hybridisation techniques were carried out as previously described. ${ }^{62}$ Hybridisation of uPAR mRNAs was done at $50^{\circ} \mathrm{C}$ for 16 hours, and the signals were detected using a Nucleic Acid Detection Kit (Boehringer Mannheim Biochemica). The slides were counterstained with haematoxylin.

The controls included: hybridisation with the sense probes; RNAse treatment before hybridisation; and use of neither the antisense RNA probe nor the antidigoxigenin antibody. The three control experiments yielded no detectable signals. Expression and distribution of signals were evaluated by two observers (SS, $\mathrm{TN}$ ) independently and blindly, and confirmed by a third observer ( $\mathrm{YH})$.

NORTHERN BLOT ANALYSIS

Northern blot analysis was carried out by a modified non-radiographic method as previously described. ${ }^{63}$ Total RNA was purified from frozen samples with ISOGEN (Nippon Gene, Tokyo, Japan). Total RNA per lane $(20 \mu \mathrm{g})$ was electrophoresed on $1 \%$ agarose gels containing $7.5 \%$ formaldehyde and transferred to nylon membranes (Nylon membranes positively charged, Boehringer Mannheim) by capillary action in $20 \times$ SSC (saline sodium citrate). The membranes were baked for 30 minutes at $120^{\circ} \mathrm{C}$ and prehybridised in prehybridisation buffer (0.5\% SDS (sodium dodecyl sulphate), $5 \times$ SSC, $10 \times$ Denhardt's solution, $10 \mathrm{mM}$ $\mathrm{Na}_{2} \mathrm{PO}_{4}, 50 \%$ formamide, $0.1 \mathrm{mg} / \mathrm{ml}$ sonicated salmon sperm DNA) for three hours at $50^{\circ} \mathrm{C}$. The RNA was probed by hybridisation at $50^{\circ} \mathrm{C}$ with DIG labelled DNA probe under prehybridisation conditions overnight. The membranes were washed with $0.2 \times$ SSC containing $0.1 \%$ SDS (20 minutes at $68^{\circ} \mathrm{C}$, twice), rinsed in DIG buffer 1 , incubated with $1 \%$ Blocking Reagent (Boehringer Mannheim) in DIG buffer 1 for 60 minutes at room temperature, incubated with $0.5 \mathrm{ml}$ antidigoxigenin alkaline phosphate conjugated antibody diluted $1 / 10000$ in DIG buffer 1 with $0.2 \%$ polyoxethylen(20)sorbitan monolaurate (Wako Pure Chemical Industries Ltd., Osaka, Japan) for 30 minutes at room temperature, then washed with DIG buffer 1 (15 minutes, twice) and rinsed with DIG buffer 3 for three minutes. For detection of signals, the membranes were incubated at $37^{\circ} \mathrm{C}$ with CSPD (disodium 3-(4-methoxyspiro(1,2-dioxetane3,2'-(5'-chloro)tricloro(3.3.1.13,7) decan)-4ly)phenyl phosphate) (Boehringer Mannheim) diluted $1 / 100$ in assay solution $(100 \mathrm{mM}$ diethanolamine, $2 \mathrm{mM} \mathrm{MgCl}, 0.02 \% \mathrm{NaN} 3$ ) for 10 minutes. Hybridisation signals were exposed to $x$ ray film (Hyperfilm-ECL, Amersham) for three hours at room temperature. After hybridisation, the blots were stripped and rehybridised with $\beta$ actin cDNA probe. The bands for uPAR mRNA were quantified with 
Table 1 Expression of UPAR $m R N A$ and protein in colorectal neoplasms

\begin{tabular}{|c|c|c|c|c|c|c|c|}
\hline & \multicolumn{3}{|l|}{ Adenoma } & \multicolumn{4}{|c|}{ Invasive carcinoma } \\
\hline & $\begin{array}{l}\text { Mild } \\
\text { dysplasia }\end{array}$ & $\begin{array}{l}\text { Moderate } \\
\text { dysplasia }\end{array}$ & $\begin{array}{l}\text { Severe } \\
\text { dysplasia }\end{array}$ & Dukes'A & Dukes'B & Dukes'C & $\begin{array}{l}\text { Liver } \\
\text { metastasis }\end{array}$ \\
\hline In situ hybridisation (\%) & $6 / 31(19)$ & $7 / 33(21)$ & $17 / 36(47)^{\star}$ & $21 / 29(72) \dagger$ & $26 / 28(93) \ddagger$ & $21 / 23(91)$ & \\
\hline Immunohistochemistry (\%) & $3 / 31(10)$ & $4 / 33(12)$ & $7 / 36(19)$ & $12 / 29(41) \dagger$ & $14 / 28(50)$ & $13 / 23(52)$ & \\
\hline Northern blot analysis (\%) & $3 / 12(25)$ & $4 / 14(29)$ & $5 / 10(50)$ & $5 / 5(100)$ & $5 / 5(100)$ & $5 / 5(100)$ & $3 / 3(100)$ \\
\hline Western blot analysis (\%) & $3 / 13(23)$ & $3 / 14(21)$ & $6 / 14(43)$ & $4 / 5(80)$ & $5 / 5(100)$ & $5 / 5(100)$ & $3 / 3(100)$ \\
\hline
\end{tabular}

${ }^{\star} \mathrm{p}<0.05$ severe dysplasia versus moderate dysplasia.

$\dagger \mathrm{p}<0.05$ Dukes' A versus severe dysplasia.

$\neq \mathrm{p}<0.05$ Dukes’ B versus Dukes’ A.
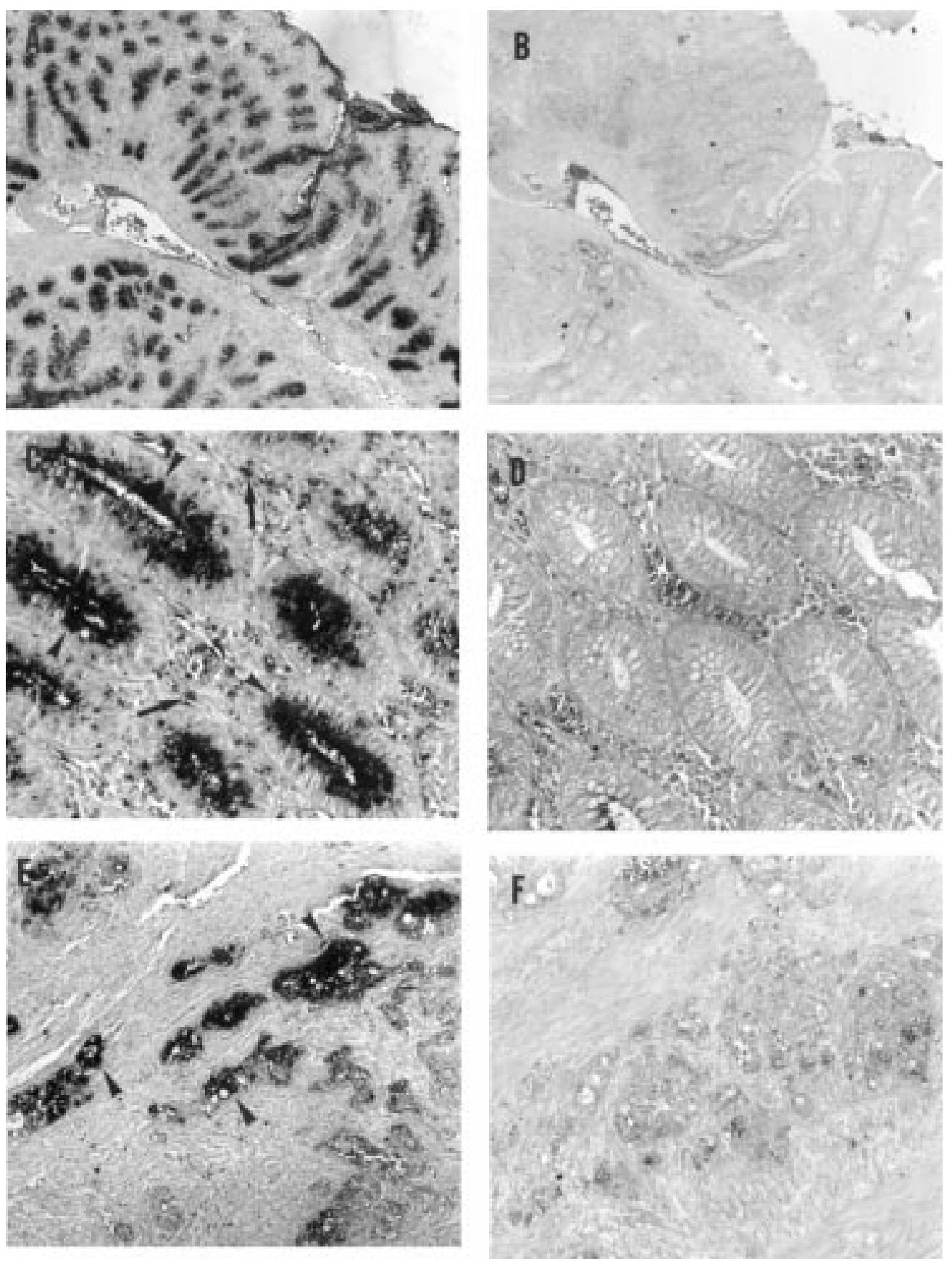

Figure 1 Localisation of uPAR gene transcript in colorectal neoplasms. (A) mild dysplasia: uPAR mRNA is present diffusely or focally in whole adenomas. (C) moderate dysplasia: uPAR mRNA shows mainly in the cytoplasm of dysplastic cells (arrowheads) and is faint in the cytoplasm of stromal cells (straight arrows) in adenomas. (E) invasive carcinoma: UPAR mRNA is strongly expressed in malignant cells on the surface of cancerous tissue, predominantly at the invasive front of the tumour (arrowheads). $(B, D, F):$ no staining was detected with the sense riboprobe in adjacent sections. 
A

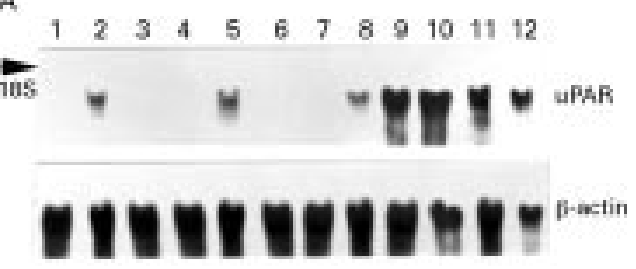

旦

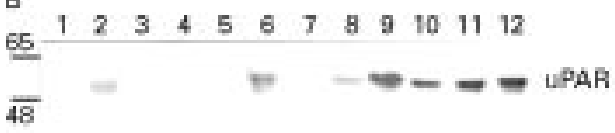

Figure 2 (A) Representative northern blot analysis of UPAR gene transcript in colorectal neoplasms. Lane 1, normal colorectal tissue; lanes 2, 3, 4, mild dysplasia; lanes 5,6 , moderate dysplasia; lanes 7, 8, severe dysplasia; lane 9, Dukes'stage A carcinoma; lane 10, Dukes'stage B carcinoma; lane 11, Dukes'stage C carcinoma; lane 12, metastatic carcinoma of the liver. The position of $18 \mathrm{~S}$ $r R N A(1.86 \mathrm{~Kb})$ is indicated. (B) Representative western blot analysis of UPAR in extracts from colorectal neoplasms with antibody no. 3937. Lane 1, normal colorectal tissue; lanes 2, 3, 4, mild dysplasia; lanes 5, 6, moderate dysplasia; lanes 7,8 , severe dysplasia; lane 9, Dukes'stage A carcinoma; lane 10, Dukes'stage B carcinoma; lane 11, Dukes'stage C carcinoma; lane 12, metastatic carcinoma of the liver. The relative position of molecular weight marker $(k D a)$ is indicated on the left.

the software NIH Image 1.55 (National Institutes of Health, Bethesda, Maryland, USA).

IMMUNOHISTOCHEMISTRY

uPAR protein expression in tissue sections was localised immunohistochemically by the monoclonal antibody against human uPAR, no. 3937 (American Diagnostic Inc., Greenwich, Connecticut). Immunohistochemical staining was done with the Large Volume DAKO LSAB Kit, Peroxidase (Dakopatts, Copenhagen, Denmark) according to the manufacturer's instructions. Formalin fixed sections $(5 \mu \mathrm{m})$ were deparaffinised in xylene (five minutes, three times), then dehydrated in ethanol, and incubated with 3\% hydrogen peroxide for 15 minutes, with blocking solution for

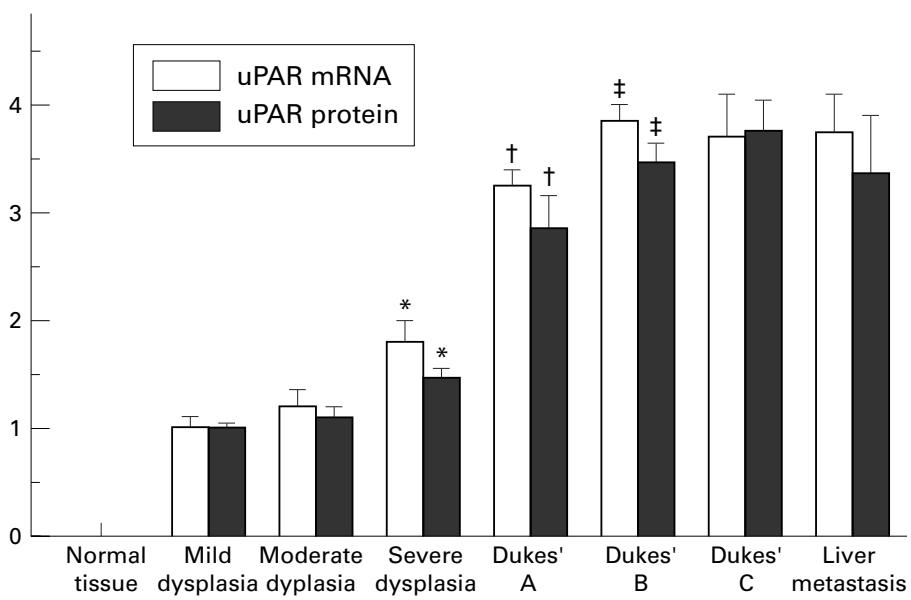

Figure 3 Densitometric analysis. UPAR $m R N A$ and protein concentrations seen on northern blots, normalised with $\beta$ actin, and western blots were quantified as the ratio of those in mild dysplasic adenoma. Results are expressed as mean (SEM). ${ }^{*} p<0.05$ compared with moderate dysplasia; $t p<0.05$ compared with severe dysplasia; $\neq p<0.05$ compared with Dukes'stage A.
30 minutes and with monoclonal antibody, no. 3937 (American Diagnostic Inc.) diluted 1/100 in $0.01 \%$ PBS for two hours at room temperature. After washing with Tris buffer, the sections were visualised with aminoethylcarbazole chromogen containing hydrogen peroxide. The sections were counterstained with haematoxylin and mounted. The staining was evaluated by three observers as well as by in situ hybridisation. When all epithelial cells of one crypt or more than $20 \%$ of 500 epithelial cells in a section were stained, the neoplasm was scored as UPAR positive.

WESTERN BLOT ANALYSIS

Western blot analysis was carried out as previously described.$^{64}$ Protein samples $(40 \mu \mathrm{g})$ were subjected to $12.5 \%$ SDS polyacrylamide gel electrophoresis (PAGE), then electrotransferred onto nitrocellulose filters (HybondECL, Amersham Corp.). The monoclonal antibody against human UPAR no. 3937 was used. Immunocomplex was detected by the enhanced chemiluminescence western blotting detection system (Amersham Corp.). Finally, the membrane was exposed to $x$ ray film (Hyperfilm-ECL, Amersham Corp.). The blots for the UPAR protein were quantified with the software NIH Image 1.55 .

\section{STATISTICS}

Data were evaluated by the $\chi^{2}$ test and the unpaired Student's $t$ test. Statistical values were considered significant when $\mathrm{p}<0.05$.

\section{Results}

IN SITU HYBRIDISATION

UPAR mRNA reactivities were scattered throughout the overall, central, and peripheral proliferating region in $30(30 \%)$ of the 100 colorectal adenomas studied: mild dysplasia $(6 / 31 ; 19 \%)$, moderate dysplasia $(7 / 33 ; 21 \%)$, and severe dysplasia $(17 / 36 ; 47 \%$ ) (fig 1A; table 1). uPAR mRNA expression was detected mainly in the cytoplasm of dysplastic epithelial cells, being faintly positive or negative in the cytoplasm of stromal cells located in the vicinity of the dysplastic glands (fig 1C). UPAR mRNA positive stromal cells revealed morphological features of inflammatory cells comprising macrophages, neutrophils, and lymphocytes. An accumulation of UPAR mRNA was detected in wholly cancerous tissue, predominantly at the advancing front in $68 / 80(85 \%)$ invasive carcinomas: Dukes' stage A (21/29; $72 \%)$, stage B $(26 / 28 ; 93 \%)$, and stage C (21/ 23 ; $91 \%$ ) (fig $1 \mathrm{E}$; table 1 ).

Strong hybridisation signals for UPAR mRNA were detected in the cytoplasm of malignant cells, and faint signals in some stromal cells around malignant glands. Significant increases in the frequency of uPAR mRNA expression were observed in severe dysplasia over that in moderate dysplasia $(p<0.05)$, in Dukes' stage A invasive carcinoma over that in severe dysplastic adenoma $(\mathrm{p}<0.05)$, and in Dukes' stage B over that in stage A $(p<0.05)$; the differences between adenoma with mild dysplasia and adenoma with moderate dysplasia, and between Dukes' stage B and stage C 

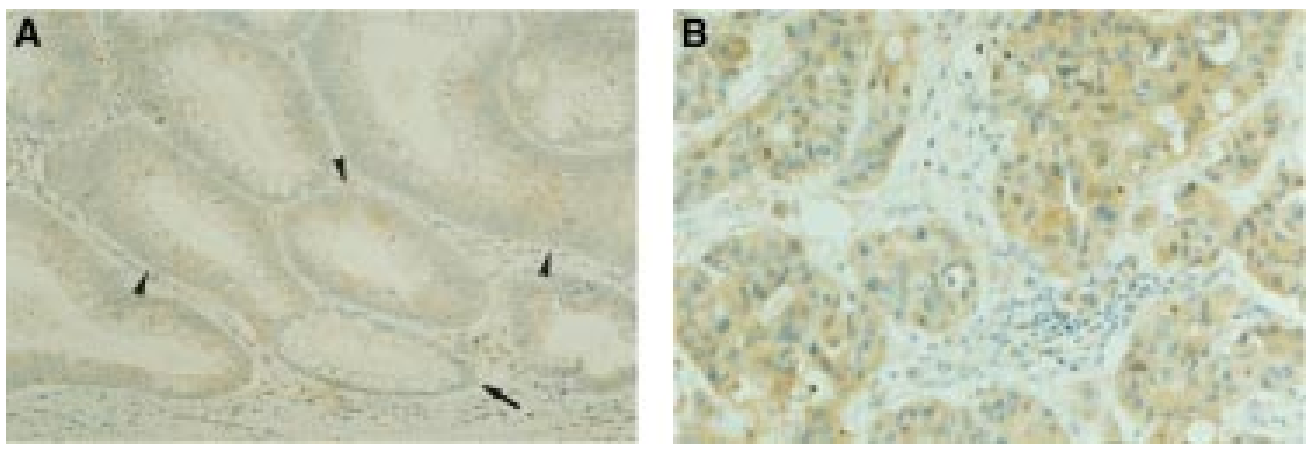

Figure 4 Immunohistochemical localisation of uPAR protein in colorectal neoplasms. (A) Faint staining was seen in the dysplastic proliferative epithelium of adenomas (arrowheads) but not in normal glands (straight arrow). (B) Intense staining was localised in carcinomatous cells, predominantly at the invasive front of the carcinoma. Immunoreactivity was detected at the plasma membrane and cytoplasm of dysplastic or carcinomatous cells. Very few or no stromal cells associated with tumours were positive.

did not however reach statistical significance. No detectable signal was seen in the normal tissue adjacent to the cancerous or adenomatous region. The distribution patterns obtained with two different probes were similar in all cases. No signal was detected with the sense riboprobe in adjacent sections (fig $1 \mathrm{~B}, \mathrm{D}, \mathrm{F}$ ).

NORTHERN BLOT ANALYSIS OF UPAR mRNA In adenomas with increasing severity of atypia, northern blot analysis showed that $3 / 12$ mild, 4/14 moderate, $5 / 10$ severe dysplasia, five of Dukes' stage A (5/5), five of stage B (5/5), five of stage $C$ tumours $(5 / 5)$, and three metastatic colorectal carcinomas of the liver (3/3) contained uPAR mRNA $1.7 \mathrm{~kb}$ in size (fig $2 \mathrm{~A}$; table 1 ), and that there was a significant correlation between UPAR mRNA level and the progressive state of the adenoma (fig 3). During the increasing severity of atypia in adenoma, although there was no significant difference in uPAR mRNA level between mild and moderate dysplasia, the level was significantly higher in severe dysplasia (1.5-fold) than in moderate dysplasia $(p<0.05)$. Furthermore, the amount of uPAR mRNA was 1.8-fold higher in Dukes' stage $A$ than in severe dysplastic adenoma $(\mathrm{p}<0.05)$ and 1.2-fold higher in Dukes' stage B than in stage A $(p<0.05)$. The level of uPAR mRNA was, however, not related to later stages of invasive carcinoma, Dukes' stage B, stage C, or to liver metastasis of colorectal carcinoma. No band for uPAR mRNA was detected in any of the seven normal tissue studies. These results corroborated those of in situ hybridisation.

\section{IMMUNOHISTOCHEMISTRY}

Immunohistochemical staining with the antibody no. 3937 against uPAR was done to examine the expression and distribution pattern of uPAR protein on sections adjacent to those used for the in situ hybridisation studies. Faint immunohistochemical staining was scattered within the proliferating region in $14 \%$ of the 100 adenomas: mild $(3 / 31 ; 10 \%)$, moderate $(4 / 33 ; 12 \%)$, and severe dysplasia $(7 / 36 ; 17 \%)$ (fig 4A; table 1). By contrast, intense staining was detected in carcinomatous cells over the surface of cancer tissue in invasive carcinomas (39/80; 49\%): Dukes' stage A $(12 / 29 ; 41 \%)$, stage B (14/28; 50\%), and stage C (13/23;
$52 \%)$ and the staining was localised predominantly at the invasive region of carcinomas (fig 4B; table 1). Immunoreactivity was recognised at the plasma membrane and cytoplasm of dysplastic epithelial and malignant cells. No positivity, but only weak signals for UPAR protein, was detected in the stroma. None of the normal colon tissue was stained. A significant increase in the frequency of UPAR protein expression was shown in Dukes' stage A over that in severe dysplastic adenoma $(p<0.05)$. There was, however, no significant difference in UPAR antigen expression during the progressive state of adenoma or invasive carcinoma (Dukes' stages A-C ).

WESTERN BLOT ANALYSIS

Western blot analysis of tissue lysates with anti-uPAR antibody no. 3937 revealed a single protein band of approximately $55 \mathrm{kDa}$, corresponding to the molecular mass of purified uPAR, in mild (3/12), moderate (3/13), and severe (6/15) dysplasia, in Dukes' stage A (4/5), stage B (5/5), and stage C (5/5), and in metastatic colorectal carcinomas of the liver (3/3) (fig 2B; table 1 ). As expected from quantitative analysis of mRNA by northern blotting, uPAR protein contents were related to the state of progression of adenoma and carcinoma (fig 3). In adenomas, the UPAR protein concentration in severe dysplasia was 1.3-fold higher than that in moderate dysplasia $(\mathrm{p}<0.05)$, and in invasive carcinoma, the concentration in Dukes' stage A was 1.8-fold higher than that in severe dysplasia and that in Dukes' stage B was 1.2 -fold higher than that in stage $A(p<0.05)$. There was no clear correlation between mild dysplasia and moderate dysplasia in adenoma or the later stages of invasive carcinoma (Dukes' stage B, stage C, or liver metastasis of colorectal carcinoma). No band for UPAR protein was detected in seven specimens of normal colon tissues.

\section{Discussion}

Extracellular proteolytic degradation regulates cancer invasion as well as tissue remodelling under physiological conditions. ${ }^{3}$ Numerous clinical and experimental studies have provided evidence of a critical role of the uPA system in cancer invasion and metastasis. ${ }^{17-32}$ One of the components of this system, uPAR expression 
on the surface of tumour cells, has proved to be central to the invasion process and to tumour progression. ${ }^{12-14}$ 18-23 44-47 Blocking uPAR expression by antisense UPAR $\mathrm{mRNA}$ or inactivation of UPA inhibits invasiveness and metastatic activity of carcinoma cells in vitro and in vivo. ${ }^{48} 49$ uPAR is also involved in angiogenesis and tumour growth. ${ }^{50}$ In contrast with carcinomas, the contribution of UPAR in premalignant lesions has received little attention.

Our study showed both the cellular expression and distribution of UPAR mRNA during the progression from colorectal adenomas with mild dysplasia to carcinoma in situ and the manifest invasive cancer revealed by in situ hybridisation and northern blot analysis. In $30 \%$ of adenomas, the UPAR gene transcript was scattered in dysplastic epithelial cells. In $85 \%$ of invasive carcinomas, strong signals for the UPAR gene transcript were detected mainly in carcinomatous cells, predominantly at the invasive edges of tumours; much weaker signals were detected in stromal cells, mainly inflammatory cells, around adenomatous or cancerous glands. Furthermore, immunohistochemical study localised the corresponding antigens to adenomatous dysplastic cells or carcinomatous cells. These findings indicate that the main source of uPAR synthesis is essentially dysplastic epithelial or carcinomatous cells in colorectal neoplasms. It should be noted that this result differs from earlier studies using in situ hybridisation and immunohistochemistry that have suggested that uPAR is produced by stromal, not dysplastic epithelial cells in adenomas. ${ }^{58} 59$

Similar discrepancies in the distribution of components of the uPA system have been noted between studies by different groups (reviewed in Andreasen et $a l^{65}$ ). In colorectal adenocarcinomas, the majority of which are considered to develop from premalignant adenomatous lesions, expression of UPAR $\mathrm{mRNA}$ and protein have been identified mainly as malignant cells similar to most types of carcinoma, ${ }^{18-23} 384344$ and in some reports, to stromal cells around cancer cells as well. ${ }^{19} 5859$ Furthermore, studies with in vitro assays have also provided evidence of uPAR upregulation in colon cancer cells. ${ }^{45-47}$ These observations confirm our results that premalignant dysplastic epithelial cells, not stromal components, are the predominant sites of UPAR expression in adenomas.

The various expression patterns of the uPA system remain to be elucidated. Several studies have shown that the production sites of UPAR may vary between different tumours of the same tissue depending on the state of differentiation. Tumour progression involves many interactions between cancer cells and extracellular matrices or stromal cells, including inflammatory cells. ${ }^{1-3}$ Infiltrating inflammatory cells represent a potential source of protease activity in tumours. Recent studies with in vitro assays have provided evidence of the important role of the uPA system in cell attachment, migration, and signal transduction, as well as in pericellular proteolysis. ${ }^{51-566667}$ uPAR expresses in monocytes/macrophages, PMNs (polymor- phonuclear neutrophil leucocytes), fibroblasts, endothelial cells, and keratinocytes in inflammation, wound healing, and angiogenesis; furthermore, UPAR expression can be regulated under the influence of cytokines and growth factors (reviewed in Vassilli et $a l^{68}$ ). Such uPAR presence on various types of cells may reflect its multitude of functions under pathological conditions involving cancer invasion and could, therefore, be controlled dynamically. Indeed, uPAR mRNA reactivity was recognised faintly in stromal, inflammatory cells in this study. For example, in vitro, endotoxin stimulates uPAR expression in inflammatory cells, and UPAR facilitates their migration ${ }^{69}$; some of the discrepancy in the distribution of UPAR expression in colorectal neoplasia may be due to differences in the state and degree of uPAR synthesis by the inflammatory cells that infiltrate around the neoplastic glands.

The increases of uPA content and proteolytic activity have been reported to associate with the adenoma-carcinoma sequence. ${ }^{34-36} 59$ In contrast with uPA, it is still unknown when dysplastic cells express the uPAR gene in colorectal carcinogenesis and whether there is a parallel correlation between uPAR expression and the histological grade of dysplasia in premalignant adenomatous lesions. Our qualitative and quantitative analyses of mRNA by in situ hybridisation and northern blotting disclosed that UPAR gene expression in dysplastic cells increased in the adenomas with increasing severity of atypia; it increased more significantly in severe dysplasia than in mild or moderate dysplasia. Furthermore, the expression increased more notably in Dukes' stage A carcinomas than in severe dysplastic adenomas, and in the more invasive Dukes' stage B carcinomas than in the less advanced Dukes' stage A carcinomas. Western blot analysis also showed that UPAR protein was coupled to a corresponding increase in UPAR mRNA. These findings suggest possible involvement of UPAR gene upregulation in the invasive behaviour of colorectal cancer. It may be assumed that in the process of the transformation of severely dysplastic epithelium containing carcinoma in situ into invasive carcinoma, cancer cells which upregulate the UPAR gene may acquire invasive phenotypes of both the capability to generate cell surface proteolytic activity by activation of receptor bound UPA and the potential to invade beyond the muscularis mucosae to the serosa and then to metastasise.

In this study, immunohistochemical staining revealed that only $14 \%$ of adenomas and $45 \%$ of invasive carcinomas displayed immunoreactive signals in both cell membranes and the cytoplasm of dysplastic epithelial or cancer cells, the signals being scattered throughout the adenomas or being most prominent in the invasive region of the cancers. The distribution pattern of the UPAR protein was similar to that of UPAR mRNA in adenomatous or carcinomatous tissues; however, the frequency of uPAR protein expression was low compared with that of mRNA. Interestingly, this dissociation between uPAR mRNA and protein 
expression agrees with studies by Pyke et al, which reported that many neoplastic cells show a prominent signal for uPAR mRNA, but do not contain detectable concentrations of UPAR protein in colon cancer. ${ }^{43}$ One possible explanation is that uPAR mRNA is not partly translated. As determined by ELISA, however, adenomas show intermediate UPAR concentrations between normal colonic mucosa and carcinomas. ${ }^{41}$ Our results by immunoblot analysis showed the expression of UPAR protein in only 12 of 41 adenomas but in 17 of 18 cancers studied; the results were corroborated by northern blot analysis. These findings suggest that the synthesis of uPAR protein is regulated at the trancriptional level, as has been shown in other types of cells. ${ }^{70-72}$ Secondly, the dissociation may be due to the rapid turnover of uPAR, a glycosyl phosphatidyl inositol (GPI) anchored protein, resulting in antigen levels that are too low to be detected by immunohistochemical staining in paraffin or frozen sections. ${ }^{69} 7374$

Immunoblot analysis, which is more sensitive than immunostaining, readily reveals uPAR antigenicity in $94 \%$ of cancers and in $29 \%$ of adenomas. The third and most likely explanation is that the detection of UPAR antigen of low frequency may be due to the presence of various UPAR molecular forms resulting from the extent of glycosylation, the presence or absence of cleavation and alternatively spliced forms. ${ }^{7-76}$ The various molecular forms cause the differences of antigenicity detected with monoclonal antibodies. Luther et al have suggested that the differences of immunoreactivity might be explained by the interference of the interaction of the MAbs with receptor bound uPA or with the extent of glycosylation. ${ }^{76}$ Furthermore, the alternative splicing of uPAR cDNA may partly explain the discrepancies in the distribution of UPAR mRNA.

Broad clinical studies have established that components of the uPA system are a prognostic marker in many malignancies. ${ }^{25-31}$ Ganesh et al have identified UPAR concentration as a prognostic factor in the comparison of patients with modified Dukes' stage B versus C in 161 colorectal cancers. ${ }^{32}$ This result partly disagrees with our inability to detect significant differences in the level of UPAR mRNA or protein between Dukes' stage B and stage C, or in morbidity or mortality. The disagreement may be a reflection of the small number of cases (15) analysed in the present study, or of the classification difference in the stages of cancer: tumours invading to muscularis propria are classified as Dukes' A, but as stage B1 according to Dukes' modified classification.

Taken together, these observations document the contribution of UPAR in colorectal premalignant lesions during cancer progression. We suggest that UPAR expresses essentially in dysplastic epithelial cells in colorectal adenomas and that the expression is upregulated with increasing severity of atypia in adenomas and increases notably during the critical transition from severe dysplastic adenoma to invasive carcinoma. These findings implicate UPAR expression in the invasive and metastatic processes of adenocarcinoma of the colon and rectum.

We thank Dr Eriko Minami, Dr Hiroshi Yoshida, and Dr Masao Shirakawa for kindly providing the adenomatous tissue samples used in this work. The expert technical assistance of Miss used in this work. The expert technical assistance of Miss Chiyomi Ikeuchi is also gratefully acknowledged. This work was
supported in part by Grants in Aid for Scientific Research supported in part by Grants in Aid for Scientific Research
(C05807014, B07457050, 08877199, and B(2)10470049) and Exploratory Research (08877199) from the Ministry of EducaExploratory Research (08877199) from the
tion, Science, Sports, and Culture, Japan.

1 Liotta LA, Steeg PS, Stetler-Stevenson WG. Cancer metatasis and angiogenesis: an imbalance of positive and negative regulation. Cell 1991;64:327-36.

2 Liotta LA. Tumor invasion and metastasis-role of the extracellular matrix. Cancer Res 1986;46:1-7.

3 Tryggvason K, Höyhtyä M, Salo T. Proteolytic degradation of extracellular matrix in tumor invasion. Biochem Biophys Acta 1987;907:191-217.

4 Liotta LA, Rao CN, Wewer UM. Biochemical interactions of tumor cells with the basement membrane. Ann Rev Biochem 1986;55:1037-57.

5 Laiho M, Keski-oja J. Growth factors in the regulation of pericellular proteolysis. Cancer Res 1989;49:2533-53.

6 Danø K, Andreasen PA, Grøndahl-Hansen J, et al. Plasminogen activators, tissue degradation and cancer. $A d v$ Plasminogen activators, tissue

7 Blasi F, Vassalli J-D, Danø K. Urokinase-type plasminogen activator: proenzyme, receptor, and inhibitors. $\mathcal{F}$ Cell Biol 1987;104:801-4

8 Keski-oja J, Kori K, Lohi J, et al. Growth factors in the reguation of plasminogen-plasmin system in tumor cells. Semin Thromb Hemost 1991;17:231-9.

9 Nakajima M, Chop AM. Tumor invasion and extracellular matrix degradative enzyme: regulation of activity by organ factors. Semin Cancer Biol 1991;2:115-27.

10 Ellis V, Behrendt N, Danø K. Plasminogen activation by receptor-bound urokinase. F Biol Chem 1991;266:12752-8.

11 Hollas W, Blasi F, Boyd D. Role of urokinase receptor in facilitating extracellular matrix invasion by cultured colon cancer. Cancer Res 1991;51:3690-5.

12 Veale D, Needham G, Harris AL. Urokinase receptors in lung cancer and normal lung. Anticancer Res 1990;10:41722 .

13 Schlechte W, Brattain M, Boyd D. Invasion of extracellular matrix by cultured colon cancer cells: dependence on urokinase receptor display. Cancer Commun 1990;2:173-9.

14 Hoosein NM, Boyd D, Hollas WJ, et al. Involvement of urokinase and its receptor in invasiveness of human prostatic carcinoma cell lines. Cancer Commun 1991;3:25564.

15 Olsen D, Pöllänen J, Høyer-Hansen G, et al. Internalization of the urokinase-plasminogen activator inhibitor type 1 complex is mediated by the urokinase receptor. 7 Biol Chem 1992;267:9129-33.

16 Baker MS, Bleakley P, Woodrow GC, et al. Inhibition of cancer cell urokinase plasminogen activator by its specific inhibitor PAI-2 and subsequent effects on extracellular matrix degradation. Cancer Res 1990;50:4676-84.

17 Nielsen BS, Sehested M, Timshel S, et al. Messenger RNA for urokinase plasminogen activator is expressed in myofibroblasts adjacent to cancer cells in human breast cancer. Lab Invest 1996;74:168-77.

18 Bianchi E, Cohen RL, Thor AT, et al. The urokinase receptor is expressed in invasive breast cancer but not in normal breast tissue. Cancer Res 1994;54:861-6.

19 Pyke C, Græm N, Ralfkiær E, et al. Receptor for urokinase is present in tumor-associated macrophages in ductal breast carcinoma. Cancer Res 1993;53:1911-5.

20 Casslén B, GusstaussonB, Åstedt B. Cell membrane receptor for urokinase plasminogen activator are increased in malignant ovarian tumours. Eur $\mathcal{F}$ Cancer 1991;27:1445-8.

21 Vries TJ, Quax PHA, Denijn M, et al. Plasminogen activators, their inhibitors, and urokinase receptor emerge in late stages of melanocytic tumor progression. $\mathrm{Am} \mathrm{f}$ Pathol 1994;144:70-81.

22 Wagner SN, Atkinson MJ, Thanner S, et al. Modulation of urokinase and urokinase receptor gene expression in human renal cell carcinoma. Am f Pathol 1995;147:18392.

23 Zheng $\mathrm{MH}$, Fan Y, Panicker A, et al. Detection of mRNAs for urokinase-type plasminogen activator, its receptor, and type 1 inhibitor in giant cell tumors of bone with in situ hybridization. Am F Pathol 1995;147:1559-66.

24 Reilly D, Christensen L, Duch M, et al. Type-1 plasminogen activator inhibitor in human breast carcinoma. Int $\mathcal{f}$ Cancer 1992;50:208-14.

25 Foekens JA, Schmidtt M, van Putten WLJ, et al. Prognostic value of urokinase-type plasminogen activator in 671 primary breast cancer patients. Cancer Res 1992;52:61015.

26 Hasui Y, Marutsuka K, Suzumiya J, et al. The content of urokinase-type plasminogen activator antigen as a prognostic factor in urinary bladder cancer. Int $f$ Cancer 1992;50:871-3.

27 Grøndahl-Hansen J, Peters HA, van Putten WLJ, et al. Prognostic significance of the receptor for urokinase plasminogen activator in breast cancer. Clin Cancer Res 1995;1:1079-87. 
28 Grøndahl-Hansen J, Christensen IJ, Rosenquist C, et al. High levels of urokinase-type plasminogen activator and its inhibitor PAI-1 in cytosolic extracts of breast carcinomas are associated

29 Ito H, Yonemura Y, Fujita H, et al. Prognostic relevance of urokinase-type plasminogen activator (uPA) and plasminogen activator inhibitors PAI-1 and PAI-2 in gastric cancer. Virchows Arch 1996;427:487-96.

30 Sier CFM, Vloedgraven HJM, Ganesh S, et al. Inactive urokinase and increased levels of its inhibitor type 1 in colorectal cancer liver metastasis. Gastroenterology 1994; 107:1449-56.

31 Ganesh S, Sier CFM, Griffioen G, et al. Prognostic relevance of plasminogen activators and their inhibitors in colorectal cancer. Cancer Res 1994;54:4065-71.

32 Ganesh S, Sier CFM, Heerding MM, et al. Urokinase receptor and colorectal cancer survival. Lancet 1994;344: 401-2.

33 Sim Pheng-Siew, Stephens RW, Fayle DRH, et al. Urokinase-type plasminogen activator in colorectal carcinomas and adenomatous polyps: quantitative expression of nomas and adenomatous polyps: quantitative expres

34 Gelister JSK, Lewin MR, Savage F, et al. Plasminogen activators in experimental colorectal neoplasia: a role in adenoma-carcinoma sequence? Gut 1987;28:816-21.

35 Suzumiya J, Hasui Y, Kohga S, et al. Comparative study of plasminogen activator antigen in colonic carcinomas and adenomas. Int $\mathcal{F}$ Cancer 1988;42:627-32.

36 de Bruin PAF, Griffioen G, Verspaget HW, et al. Plasminogen activator profiles in neoplastic tissues of the human colon. Cancer Res 1988;48:4520-4.

37 de Bruin PAF, Griffioen G, Verspaget HW, et al. Plasminogen activators and tumor development in the human colon: activity level in normal mucosa, adenomatous polyps, and adenocarcinomas. Cancer Res 1987;47:4654-7.

38 Pyke C, Kristensen P, Ralfkiær E, et al. Urokinase-type plasminogen activator is expressed in stromal cells and its minogen activator is expressed in stromal cells and its receptor in cancer cells at invasive foci in huma

39 Sier CFM, Fellbaum C, Verspaget HW, et al. Immunolocalization of urokinase-type plasminogen activator in adenomas and carcinomas of the colorectum. Histopathology 1991;19:231-7.

40 Pyke C, Kristensen P, Ralfkiær E, et al. The plasminogen activator system in human colon cancer: messenger RNA
for the inhibitor PAI-1 is located in endothelial cells in the tumor stroma. Cancer Res 1991;51:4067-71

41 Sier CFM, Quax PHA, Vloedgraven HJM, et al. Increased urokinase receptor levels in human gastrointestinal neoplasia and related liver metastasis. Invasion Metastasis 1993;13: 277-88.

42 Sier CFM, Verspaget HW, Griffioen G, et al. Imbalance of plasminogen activators and their inhibitors in human colorectal neoplasia. Gastroenterology 1991;101:1522-8.

43 Pyke C, Ralfkiær E, Rønne E, et al. Immunohistochemical detection of the receptor for urokinase plasminogen activadetection of the receptor for urokinase plasminogen activa-
tor in human colon cancer. Histopathology 1994;24:131-8.

44 Morita Y, Hayashi Y, Wang Y, et al. Expression of urokinasetype plasminogen activator receptor in hepatocellular

45 Cohen RL, Xi X-P, Crowley CW, et al. Effects of urokinase receptor occupancy on plasmin generation and proteolysis of basement membrane by human tumor cells. Blood 1991; 78:479-87.

46 Peiter LS, Kruithof EKO, Cajot J-F, et al. The role of the urokinase receptor in extracellular matrix degradation by HT 29 human colon carcinoma cells. Int f Cancer 1993;53: 444-50.

47 Wang H, Skibber J, Juarez J, et al. Transcriptional activation of the urokinase receptor gene in invasive colon cancer. Int $\mathcal{F}$ Cancer 1994;58:650-7.

48 Crowley CW, Cohen RL, Lucas BK, et al. Prevention of metastasis by inhibition of urokinase receptor. Proc Nat Acad Sci USA 1993;90:5021-5.

49 Kook YH, Adamski J, Zelent A, et al. The effect of antisense inhibition of receptor in human squamous cell carcinom inhibition of receptor in human squamous
on malignancy. $E M B O \mathcal{F}$ 1994;13:3983-91.

50 Min HY, Doyle LV, Vitt CR, et al. Urokinase receptor antagonists inhibit angiogenesis and primary tumor growth in syngeneic mice. Cancer Res 1996;56:2428-33.

51 Wei Y, Waltz DA, Rao N, et al. Identification of the urokinase receptor as an adhesion receptor for vitronectin. f Biol Chem 1994;269:32380-8.

52 Stahl A, Mueller BM. Binding of urokinase to its receptor promotes migration and invasion of human melanoma cells in vitro. Cancer Res 1994;54:3066-71.
53 Nip J, Rabbani SA, Shibata HR, et al. Coordinated expression of the vitronectin receptor and the urokinase-type plasminogen activator receptor in metastatic melanoma cells. 7 Clin Invest 1994;95:2096-103.

54 Wei Y, Lukashev M, Simon DI, et al. Regulation of integrin function by the urokinase receptor. Science 1996;273:15515.

55 Xue W, Mizutani I, Todd III RF, et al. Urokinase-type plasminogen activator receptors associate with b1 and b3 integrins of fibrosarcoma cells: dependence on extracellular matrix components. Cancer Res 1997;57:1682-9.

56 Waltz DA, Natkin LR, Fujita RM, et al. Plasmin and plasminogen activator inhibitor type 1 promote cellular motility by regulating the interaction between the urokinase receptor and vitronectin. F Clin Invest 1997;100: $58-67$

57 Muto T, Bussey HJR, Morson BC. The evolution of cancer of the colon and rectum. Cancer 1975;36:2251-70.

58 Delbaldo C, Cunningham M, Vassalli JD, et al. Plasmincatalyzed proteolysis in colorectal neoplasia. Cancer Res 1995;55:4688-95.

59 Sordat I, Chaubert P, Protiva P, et al. In situ stromal expression of the urokinase/plasmin system correlates with epithelial dysplasia in colorectal adenomas. Am $\mathcal{F}$ Pathol 1997; 150:283-95.

60 Jass JR, Sobin LH. Histological typing of intestional tumours. In: WHO international histological classification of tumours. Berlin: Springer-Verlag, 1989.

61 Dukes EC. The classification of cancer of the rectum. $f$ Pathol Bacteriol 1932;35:323-32.

62 Springer JE, Robbins E, Gwag BJ, et al. Non-radiographic detection of nerve growth factor receptor (NGFR) mRNA in rat brain using in situ hybridization histochemistry. $\mathcal{F}$ Histochem Cytochem 1991;39:231-4

63 Kohri K, Nomura S, Kitamura Y, et al. Structure and expression of the mRNA encoding urinary stone protein (osteopontin). F Biol Chem 1993;268:15180-4.

64 Kameda T, Yasui W, Yoshida K, et al. Expression of eRBB2 in human gastric carcinomas: relationship between p185 $5^{\mathrm{CRBB} 2}$ expression and the gene amplification. Cancer Res p1 $185^{\mathrm{eRBB} 2}$ expression
1990;50:8002-9.

65 Andreasen PA, Kjøller L, Christensen L, et al. The urokinase-type plasminogen activator system in cancer metastasis: a review. Int f Cancer 1997;72:1-22

$66 \mathrm{Li} \mathrm{C}$, Liu J-N, Gurewich V. Urokinase-type plasminogen activator-induced monocyte adhesion requires a carboxylterminal lysine and cAMP-dependent signal transduction. f Biol Chem 1995;270:30282-5.

67 Resnati M, Guttinger M, Valcamonica S, et al. Proteolytic cleavage of the urokinase receptor substitutes for the agonist-induced chemotactic effect. $E M B O \neq 1996 ; 15$ : $1572-82$.

68 Vassalli J-D, Sappino A-P, Belin D. The plasminogen activator/plasmin system. F Clin Invest 1991;88:1067-72.

69 Almus-Jacobs F, Varki N, Sawdey MS, et al. Endotoxin stimulates expression of the murine urokinase receptor gene in vitro. Am F Pathol 1995;147:688-98

70 Dang J, Wang Y, Doe WF. Sodium butyrate inhibits expression of urokinase and its receptor mRNAs at both transcription and post-transcription level in colon cancer cells. FEBS Lett 1995;359:147-50.

71 Antalis TM, Reeder JA. Butyrate regulates gene expression of the plasminogen activating system in colon cancer cells. Int 7 Cancer 1995;62:619-26.

72 Lund LR, Ellis V, Rønne E, et al. Transcriptional and post transcriptional regulation of the receptor for urokinasetype plasminogen activator by cytokines and tumor promoters in the human lung carcinoma cell line A549. Biochem $\mathcal{F}$ 1995;310:345-52.

73 Ploug M, Rønne E, Behrendt N, et al. Cellular receptor for urokinase plasminogen activator carboxyl-terminal processing and membrane anchoring by glycosylphosphatidyl-inositol. F Biol Chem 1991;266:1926-33.

74 Behrendt N, Rønne E, Danø K. The structure and function of the urokinase receptor, a membrane protein governing plasminogen activation on the cell surface. Biol Chem Hoppe-Seyler 1995;376:269-79.

75 Behrent N, Ronne E, Ploug M, et al. The human receptor for urokinase plasminogen activator: $\mathrm{NH} 2$-terminal amino acid sequence and glycosylation vaariants. $7 \mathrm{Biol}$ Chem 1990:265:6453-60.

76 Luther T, Magdolen V, Albrecht S, et al. Epitope-mapped monoclonal antibodies as tools for functional and morphological analyses of the human urokinase receptor in tumor tissue. Am f Pathol 1997;150:1231-44. 